\title{
Effects of cinobufacini injection on cell proliferation and the expression of topoisomerases in human HepG-2 hepatocellular carcinoma cells
}

\author{
YING LIU*, LI-YING BAN*, XI SU, SHAN GAO, JI-WEI LIU and XIAO-NAN CUI \\ Department of Oncology, The First Affiliated Hospital of Dalian Medical University, Dalian, Liaoning 116011, P.R. China
}

Received July 11, 2014; Accepted March 9, 2015

DOI: $10.3892 / \mathrm{mmr} .2015 .3552$

\begin{abstract}
The present study aimed to investigate the effects of cinobufacini injection on the proliferation and expression of topoisomerases in human HepG-2 hepatocarcinoma cells. The cells were divided into a control group and an experimental group, in which $0.105,0.21,0.42 \mathrm{mg} / \mathrm{l}$ cinobufacini was injected. Cell proliferation was assessed using a 3-(4,5-dimethylthiazol-2-yl) -2,5-diphenyltetrazolium bromide assay, levels of apoptosis were detected using annexin V/propidium iodide staining and cell cycles were analyzed using flow cytometric analysis. The mRNA and protein expression levels of topoisomerase (TOPO) I and TOPO II were determined by reverse transcription-quantitative polymerase chain reaction and western blotting, respectively. Cinobufacini injection significantly inhibited the proliferation of the HepG-2 cells $(\mathrm{P}<0.05)$, induced apoptosis $(\mathrm{P}<0.05)$ in a dose- and time-dependent manner, induced tumor cell arrest at the $S$ phase in a dose-dependent manner, and downregulated the mRNA and protein expression levels of TOPO I and TOPO II $(\mathrm{P}<0.05)$ in a dose-dependent manner. Therefore, cinobufacini was found to inhibit human HepG-2 hepatocellular carcinoma cell proliferation, and downregulation of the expression levels of TOPO I and TOPO II may contribute to the effect on proliferation observed in the Hep- $\mathrm{G}_{2}$ cells following cinobbufacini injection.
\end{abstract}

\section{Introduction}

Cinobufacini, or Huachansu, is an aqueous extract found in the skin and parotid venom glands of the toad, Bufo

Correspondence to: Professor Xiao-Nan Cui or Professor Ji-Wei Liu, Department of Oncology, The First Affiliated Hospital of Dalian Medical University, 222 Zhongshan Road, Dalian, Liaoning 116011, P.R. China

E-mail: cxn23@sina.com

E-mail: jiweiliudl@126.com

*Contributed equally

Key words: cinobufacini injection, HepG-2 cells, proliferation, apoptosis, topoisomerase I, topoisomerase II gargarizans Cantor from the family Bufonidae (1). It has been approved by the Chinese State Food and Drug Administration (ISO9002) as a medicine for tumor therapy (2). Since the 1970s, it has been widely used in tumor therapy and clinical data has demonstrated that cinobufacini injection exhibits efficacy in various types of cancer, including liver, stomach, pancreatic, esophageal (3) and lung cancer. Additionally, it can reverse multidrug resistance (4), particularly in non-responsive cancer, including liver cancer. Cinobufacini injection demonstrates efficacy in a synergistic action when combined with conventional chemotherapy and radiotherapy (5). The major pharmacological constituents of cinobufacini are bufodienolides, which include bufalin, cinobufagin, resibufogenin, bufotalin and lumichrome, alkaloids, biogenic amines, peptides and proteins $(6,7)$.

Hepatic carcinoma is one of the most common types of malignant tumor worldwide. The response of hepatic carcinoma to chemotherapy is known to be $<20 \%$ (8). Targeted drugs, including sorafenib, demonstrate only a mild increase in the survival rates of patients with hepatic carcinoma. Therefore, an efficient drug for the treatment of hepatic carcinoma is required $(9,10)$.

Clinical practice has indicated that cinobufacini injection has beneficial effects in patients with liver cancer in the control of tumour progression, improvement of signs and symptoms, and enhanced quality of life. However, the molecular mechanisms underlying cinobufacini injection remain to be fully elucidated.

Topoisomerase (TOPO), including TOPO I and TOPO II, are key enzymes in the regulation of nucleic acid topology configurations, and topoisomerases have become important targets for antitumor drugs (11-13). However, there have been no previous reports demonstrating the association between cinobufacini and topoisomerases. Therefore, the present study aimed to investigate the effects of cinobufacini injection on the proliferation, apoptosis, cell cycle arrest, and TOPO I and TOPO II expression levels in human HepG-2 hepatocarcinoma cells.

\section{Materials and methods}

Drugs and reagents. Injectable cinobufacini (cat. no. 100207-1), the content of which was measured by using one of its components, indole alkaloids, as a scalar, 
was provided by Anhui Jingchan Pharmaceutical Co., Ltd (Anhui, China). The 3-(4,5-dimethylthiazol-2-yl)-2,5-diphenyltetrazolium bromide (MTT) was purchased from BioSharp (Hefei, China) and an annexin V (AV) kit was purchased from Molecular Probes (Life Technologies, Carlsbad, CA, USA). A reverse transcription quantitative-polymerase chain reaction (RT-qPCR) kit and PCR amplification primers were purchased from Takara Bio, Inc. (Dalian, China). Mouse anti-human TOPO I monoclonal antibody (cat. no. sc-32736) and mouse anti-human TOPO II monoclonal antibody (cat. no. sc-166934) were purchased from Santa Cruz Biotechnology, Inc. (Santa Cruz, CA, USA), and horseradish peroxidase-labeled rabbit anti-mouse immunoglobulin (Ig) $\mathrm{G}$ was purchased from Beijing Zhongshan Jinqiao Biological Biotechnology Co., Ltd. (Beijing, China).

Cell lines and cultures. The human HepG-2 hepatocarcinoma cell line was provided by the Central Laboratory of The First Affiliated Hospital of Dalian Medical University (Dalian, China). The cells were incubated in low-carbohydrate Iscove's modified Dulbecco's medium (Gibco Life Technologies, Grand Island, NY, USA), supplemented with $10 \%$ fetal bovine serum (Gibco Life Technologies) and cultivated in a humidified atmosphere with $5 \% \mathrm{CO}_{2}$ at $37^{\circ} \mathrm{C}$. The culture media was replaced every second day, and the cells were digested and passaged using $0.25 \%$ trypsin (Gibco Life Technologies). When the growth of the HepG-2 cells was at $~ 90 \%$ confluence and a monolayer had formed, the cells in the logarithmic growth phase were collected for use in the subsequent experiments.

MTT assay for cell proliferation. Cell proliferation was evaluated using an MTT colorimetric assay. The HepG-2 cells in the logarithmic growth phase were seeded at a density of 5,000 cells/well in 96-well plates and incubated in a $\mathrm{CO}_{2}$ incubator at $37^{\circ} \mathrm{C}$ to allow the cells to adhere. Following incubation for $24 \mathrm{~h}$ in culture medium, different concentrations of cinobufacini $(0.105,0.21$ and $0.42 \mathrm{mg} / \mathrm{l})$ were added to the treated group via injection, and the cells were incubated for an additional 24,48 and $72 \mathrm{~h}$ at $37^{\circ} \mathrm{C}$. For each drug concentration, eight repeat wells were used. Cells without cinobufacini were used as the control group for each plate. Following incubation, $20 \mu \mathrm{l}$ MTT reagent $(5 \mathrm{~g} / \mathrm{l})$ was added to each well and the cells were incubated for $4 \mathrm{~h}$ at $37^{\circ} \mathrm{C}$. The medium and MTT was subsequently removed and $150 \mu \mathrm{l}$ dimethylsulfoxide (Amresco, LLC, Solon, OH, USA) was added to each well, following which the plate was placed on a plate shaker (Shanghai P\&S Electronics Co., Ltd., Shanghai, China) for $6 \mathrm{~min}$ at room temperature to dissolve the water-insoluble formazan. Finally, the absorbance (A) was measured at $570 \mathrm{~nm}$ using an SP-2012 ultraviolet spectrophotometer (Shanghai Spectrum Instruments Co., Ltd., Shanghai, China). The inhibitory rate (IR) was calculated using the following formula: IR\% $=(1-$ $\left.\mathrm{A}_{\text {treated }} / \mathrm{A}_{\text {control }}\right) \times 100 \%$, where $\mathrm{A}_{\text {treated }}$ is the mean absorbance of the experimental sample and $\mathrm{A}_{\text {control }}$ is the mean absorbance of the untreated control group. The half maximal inhibitory concentration $\left(\mathrm{IC}_{50}\right)$ values were calculated using SPSS 11.5 software (SPSS, Inc., Chicago, IL, USA). All experiments were performed at least three times and the representative data are presented.
Apoptosis detection using AV/propidium iodide (PI) staining. The cells were seeded into 6 -well plates $\left(0.5 \times 10^{6}\right.$ cells/well $)$, incubated overnight, treated with the selected concentrations of cinobufacini injection $(0,0.105,0.21$ and $0.42 \mathrm{mg} / \mathrm{l})$ and incubated for 24 and $48 \mathrm{~h}$. To assess the apoptotic rate, the cells were washed twice with ice-cold phosphate-buffered saline (PBS; $\mathrm{pH}$ 7.4), resuspended in a binding buffer (Fermentas, Beijing, China), containing $10 \mathrm{mM}$ HEPES (pH 7.4), $140 \mathrm{mM} \mathrm{NaCl}$ and $2.5 \mathrm{mM} \mathrm{CaCl}_{2}$, and incubated with $10 \mu \mathrm{l} / \mathrm{ml} \mathrm{AV}$ and $5 \mu \mathrm{l} / \mathrm{ml} \mathrm{PI}$ for $15 \mathrm{~min}$ in the dark at room temperature. The fluorescence of AV and PI were monitored using a fluorescence-activated cell sorting flow cytometer (Becton Dickinson, San Jose, CA, USA), and the data were analyzed using CellQuest version 5.1 software (Becton Dickinson). The experiment was repeated three times.

Cell cycle analysis using flow cytometry. The cells were seeded into 6 -well plates $\left(0.5 \times 10^{6}\right.$ cells/well $)$ and incubated overnight. The cells were then treated with the selected concentrations $(0,0.105,0.21$ and $0.42 \mathrm{mg} / \mathrm{l})$ of cinobufacini injection for $24 \mathrm{~h}$. The attached cells were subsequently harvested by trypsinization, washed twice with ice-cold PBS and fixed in ice-cold $70 \%$ ethanol (Kermel Chemical Reagent Co., Ltd., Tianjin, China) overnight at $-20^{\circ} \mathrm{C}$. The samples were washed twice with PBS and then resuspended at a concentration of $1 \times 10^{6}$ cells $/ \mathrm{ml}$. The cells were incubated with $20 \mu \mathrm{g} / \mathrm{ml} \mathrm{RNaseA} \mathrm{(Boehringer} \mathrm{Mannheim,} \mathrm{Indianapolis,}$ IN, USA) and $10 \mu \mathrm{g} / \mathrm{ml} \mathrm{PI}$ at $37^{\circ} \mathrm{C}$ in the dark for $30 \mathrm{~min}$ to ensure maximal labeling of the DNA. Finally, the samples were analyzed for cell cycle distribution using flow cytometric analysis, and the data were analyzed using CellQuest software. The experiment was repeated three times.

RT-qPCR assays to assess the mRNA expression levels of TOPO I and TOPO II. The cells in the logarithmic growth phase $\left(5 \times 10^{5}\right.$ cells/well) were seeded into 24 -well plates and cultured for $48 \mathrm{~h}$. Cinobufacini injections at different concentrations $(0,0.1050 .21$ and $0.42 \mathrm{mg} / \mathrm{l})$ were added to each group. Following incubation for $48 \mathrm{~h}$, the cells were collected. The total cellular RNA was extracted using TRIzol reagent (Invitrogen Life Technologies, Carlsbad, CA, USA), according to the manufacturer's instructions, and the concentration of total RNA was measured using a visible light spectrophotometer (ND2000; Thermo Fisher Scientific, Waltham, MA, USA). Deionized water was added to the RNA samples to result in a final concentration of $500 \mathrm{ng} / \mu \mathrm{l}$. The total RNA from each sample was reverse-transcribed using a Takara RNA PCR kit (AMV) Ver3.0 (Takara Biotechnology Co., Ltd.). The resulting cDNA was then amplified by qPCR. The following primers were used: TOPO I, forward 5'-CGCTATCCTGAAGGCATCAA-3' and reverse 5'-CTGGAGGAGGAGAAGGAACC-3', (565 bp); TOPO II, forward 5'-CTTGTACTGCAGACCCACA-3' and reverse 5'-ATAATAGAATCAAGGGAATTCCCAAGTC-3' (233 bp); and $\beta$-actin, forward 5'-GGACTTCGAGCAAGAGATGG-3' and reverse 5'-ACATCTGCTGGAAGGTGGAC-3' (404 bp). $\beta$-actin was used as an internal control to determine the quality of the RNA samples. The qPCR reaction conditions for TOPO I and TOPO II were as follows: Predenaturation at $94^{\circ} \mathrm{C}$ for $5 \mathrm{~min}$; 10 cycles of denaturation at $94^{\circ} \mathrm{C}$ for $30 \mathrm{sec}$ 
and annealing at $60^{\circ} \mathrm{C}$ for $1 \mathrm{~min} ; 25$ cycles of denaturation at $94^{\circ} \mathrm{C}$ for $30 \mathrm{sec}$, annealing at $53^{\circ} \mathrm{C}$ for $30 \mathrm{sec}$, extension at $72^{\circ} \mathrm{C}$ for $30 \mathrm{sec}$; extension at $72^{\circ} \mathrm{C}$ for $7 \mathrm{~min}$. The PCR reaction conditions for $\beta$-actin were as follows: Predenaturation at $94^{\circ} \mathrm{C}$ for $5 \mathrm{~min} ; 30$ cycles of denaturation at $94^{\circ} \mathrm{C}$ for $30 \mathrm{sec}$, annealing at $60^{\circ} \mathrm{C}$ for $1 \mathrm{~min}$ and extension at $72^{\circ} \mathrm{C}$ for $1 \mathrm{~min}$; extension at $72^{\circ} \mathrm{C}$ for $10 \mathrm{~min}$. The amplified products were analyzed by agarose gel (Life Technologies, Carlsbad, CA, USA) electrophoresis for $30 \mathrm{~min}$ on a $1.5 \%$ gel with TBE buffer (Keygen Biotech. Co., Ltd., Nanjing, China). The bands were analyzed using a GD8000 Imager (UVP, Inc., Upland, CA, USA). The experiments were repeated three times.

Western blot analysis to determine the protein expression levels of TOPO I and II. The cells in the logarithmic growth phase were seeded into four $25 \mathrm{~cm}^{2}$ culture flasks at a density of $5 \times 10^{5}$ cells $/ \mathrm{ml}$, and incubated for $24 \mathrm{~h}$. Following incubation, the cells were treated with cinobufacini injection at different concentrations $(0,0.105,0.21$ and $0.42 \mathrm{mg} / \mathrm{l})$ for $24 \mathrm{~h}$, washed three times with ice-cold PBS and lysed with prepared lysis buffer (Keygen Biotech. Co., Ltd.) for $30 \mathrm{~min}$ on ice. The debris was subsequently removed by centrifugation at $12,000 \mathrm{x} \mathrm{g}$ for $12 \mathrm{~min}$ at room temperature. The protein concentrations of the supernatants were determined using the Bradford method $(14,15)$. Equal quantities of protein $(50 \mu \mathrm{g} /$ well) were subjected to electrophoresis using sodium dodecyl sulfate-polyacrylamide gel (Keygen Biotech. Co., Ltd.) electrophoresis (5\% stacking gel $+8 \%$ separating gel), which were then transferred onto polyvinylidene difluoride membranes (Sigma-Aldrich, St. Louis, MO, USA). The membranes were incubated in blocking solution $(5 \%$ skim milk; BD Biosciences, Franklin Lakes, NJ, USA) for $1 \mathrm{~h}$ and were subsequently incubated overnight with mouse monoclonal anti-human primary antibody against TOPO I or TOPO II at $4^{\circ} \mathrm{C}$. The membrane was washed three times with Tris-buffered saline $(10 \mathrm{mM}$ Tris- $\mathrm{HCl}, 0.15 \mathrm{M} \mathrm{NaCl}$ and $8 \mathrm{mM}$ sodium azide), containing $0.05 \%$ Tween-20 (TBST; Solarbio Science \& Technology Co., Ltd., Beijing, China), and incubated with horseradish peroxidase-labeled rabbit anti-mouse $\operatorname{IgG}$ secondary antibody for $1 \mathrm{~h}$ at room temperature. Following incubation, the membrane was washed with TBST three more times. The protein bands were visualized on Kodak X-ray film using an enhanced chemiluminescence system (Amersham; GE Healthcare Bio-Sciences, Pittsburgh, PA, USA). The intensity ratios of the bands, compared with those of the control were analyzed using ImageJ v2.1.4.7 software (National Institutes of Health, Bethesda, MA, USA). The experiments were repeated three times.

Statistical analysis. SPSS 11.5 statistical software (SPSS, Inc., Chicago, IL, USA) was used for data analysis, and the normally distributed data are expressed as the mean \pm standard deviation. The data between multiple groups were compared using one-way analysis of variance. $\mathrm{P}<0.05$ was considered to indicate a statistically significant difference.

\section{Results}

Cinobufacini injection decreases the viability and growth of HepG-2 cells. The effect of cinobufacini on the viability of

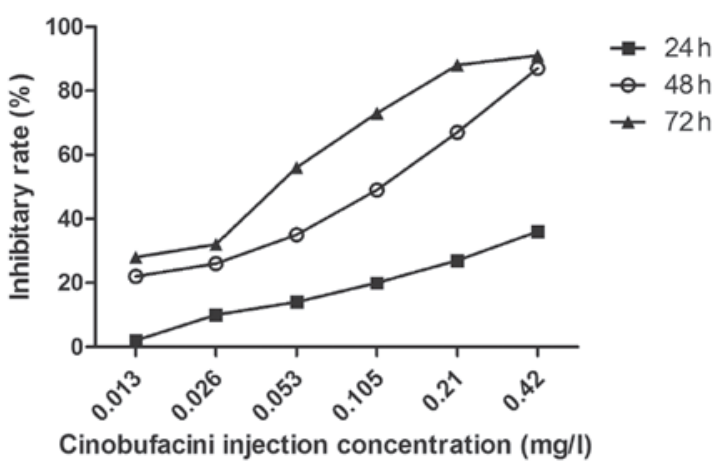

Figure 1. Cinobufacini injection has an inhibitory effect on the proliferation of HepG-2 cells. The effect of different doses of cinobufacini injection on cell proliferation at different time periods was examined. Cinobufacini injection significantly decreased the growth of the HepG-2 cells compared with the control group $(0.86 \pm 0.03,0.08 \pm 0.01$ and $0.04 \pm 0.06 \mathrm{mg} / 1$ for 24,48 and $72 \mathrm{~h}$, respectively), and the inhibitory effect was dose- and time-dependent. The data are expressed as the mean \pm standard deviation.

HepG-2 cells was determined using an MTT assay. As shown in Fig. 1, the proliferation rate of the cells was affected by the concentration of cinobufucini and the duration of treatment. The cinobufacini injection significantly decreased the growth of HepG-2 cells compared with the control group. The $\mathrm{IC}_{50}$ concentrations were $0.86 \pm 0.03,0.08 \pm 0.01$ and $0.04 \pm 0.06 \mathrm{mg} / 1$ following treatment for 24,48 and $72 \mathrm{~h}$, respectively, and the inhibitory effect occured in a dose- and time-dependent manner. These data suggested that the cinobufacini injection had an inhibitory effect on the proliferation of the HepG-2 cells.

Cinobufacini injection induces dose- and time-dependent apoptosis in HepG-2 cells. The effect of cinobufacini injection on the apoptosis of HepG-2 cells was assessed using AV/PI staining. Following treatment with different concentrations $(0,0.105,0.21$ and $0.42 \mathrm{mg} / \mathrm{l})$ of cinobufacini for $24 \mathrm{~h}$ and $48 \mathrm{~h}, \mathrm{AV} / \mathrm{PI}$ staining was performed to quantify the percentage of apoptotic cells in the total cell population using flow cytometry. The percentages of apoptotic cells following injection with $0.42,0.21$ and $0.105 \mathrm{mg} / \mathrm{l}$ of cinobufacini were $35.35 \pm 1.87,27.52 \pm 1.22$ and $17.51 \pm 1.03 \%$ following $24 \mathrm{~h}$ treatment, and $67.87 \pm 1.49,59.22 \pm 2.65$ and $37.02 \pm 1.58 \%$ following $48 \mathrm{~h}$ treatment, respectively. These values were significantly higher compared with those of the control group following $24 \mathrm{~h}(1.25 \pm 0.53 \% ; \mathrm{P}<0.05)$ and $48 \mathrm{~h}(1.25 \pm 0.53 \% ; \mathrm{P}<0.05)$ treatment and demonstrated dose- and time-dependency (Fig. 2). These data suggested that cinobufacini injection effectively induced dose- and time-dependent apoptosis in the HepG-2 cells.

Cinobufacini injection induces cell cycle arrest at the $S$ phase in HepG-2 cells. Following treatment with cinobufacini injection at different concentrations $(0,0.105,0.21$ and $0.42 \mathrm{mg} / \mathrm{l}$ ) for $24 \mathrm{~h}$, the cell cycle distributions of the HepG-2 cells were analyzed using flow cytometry. The percentages of cells in S phase were $24.85 \pm 0.85,31.46 \pm 0.98$ and $42.66 \pm 1.12 \%$ following $24 \mathrm{~h}$ treatment with $0.105,0.21$ and $0.42 \mathrm{mg} / \mathrm{l}$ cinobufacini injection, respectively. All these values were markedly higher compared with the control 
A

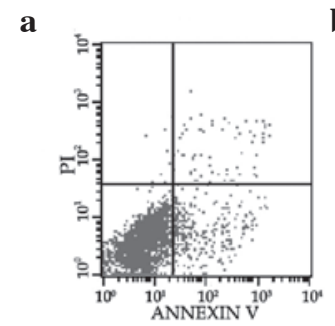

b

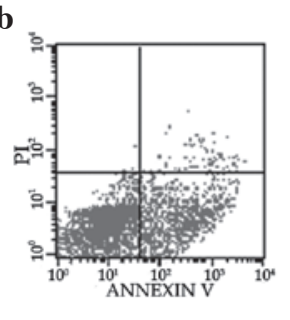

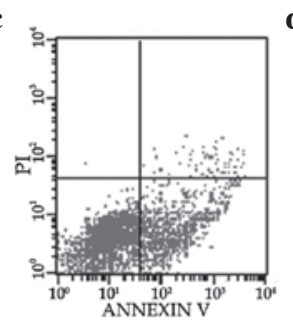

d

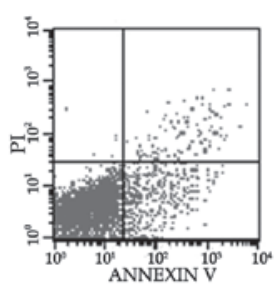

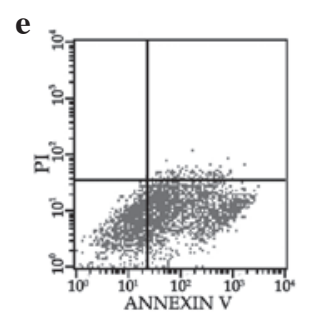

$\mathbf{f}$
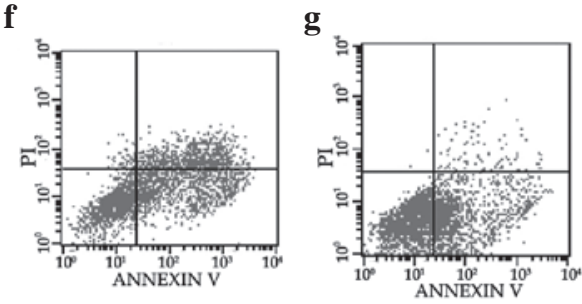

B

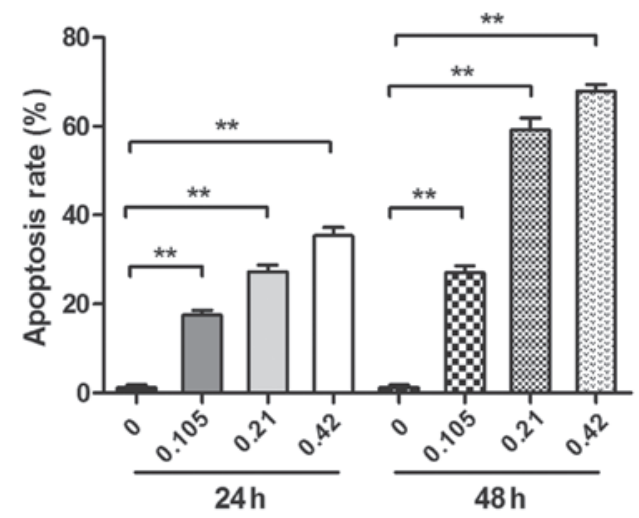

Cinobufacini injection concentration (mg/l)

Figure 2. Cinobufacini injection induces dose- and time-dependent apoptosis in HepG-2 cells. (A) Effect of different doses of cinobufacini injection (0, $0.105,0.21$, and $0.42 \mathrm{mg} / \mathrm{l}$ ) for 24 and $48 \mathrm{~h}$ on apoptosis in HepG-2cells. (a) Control; (b) $0.105 \mathrm{mg} / \mathrm{l}$ cinobufacini injection for $24 \mathrm{~h}$, (c) $0.21 \mathrm{mg} / \mathrm{l}$ cinobufacini injection for $24 \mathrm{~h}$, (d) $0.42 \mathrm{mg} / \mathrm{l}$ cinobufacini injection for $24 \mathrm{~h}$, (e) $0.105 \mathrm{mg} / \mathrm{l}$ cinobufacini injection for $48 \mathrm{~h}$, (f) $0.21 \mathrm{mg} / \mathrm{l}$ cinobufacini injection for $48 \mathrm{~h}$, (g) $0.42 \mathrm{mg} / \mathrm{l}$ cinobufacini injection for $48 \mathrm{~h}$. (B) Percentages of apoptotic cells were $35.35 \pm 1.87,27.52 \pm 1.22$ and $17.51 \pm 1.03 \%$ after $24 \mathrm{~h}$, and $67.87 \pm 1.49$, $59.22 \pm 2.65$ and $37.02 \pm 1.58 \%$ after $48 \mathrm{~h}$, when treated with $0.42,0.21$, and $0.105 \mathrm{mg} / 1$ cinobufacini, respectively. These values were significantly higher compared with those of the control group after $24 \mathrm{~h}(1.25 \pm 0.53 \% ; \mathrm{P}<0.05)$ and $48 \mathrm{~h}(1.25 \pm 0.53 \% ; \mathrm{P}<0.05)$, and were dose- and time-dependent. The data are expressed as the mean \pm standard deviation. ${ }^{* *} \mathrm{P}<0.01$. PI, propidium iodide.

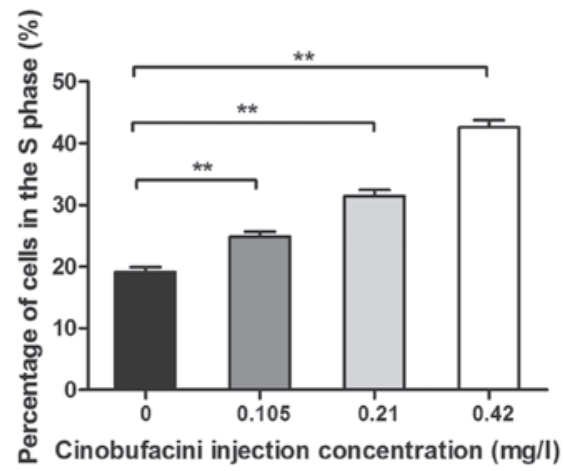

Figure 3. Cinobufacini injection induces cell cycle arrest at the $\mathrm{S}$ phase in HepG-2 cells. The effect of different doses of cinobufacini injection $(0,0.105$, 0.21 and $0.42 \mathrm{mg} / \mathrm{l}$ ) for $24 \mathrm{~h}$ on the cell cycle in HepG-2 cells was determined. The data are expressed as the mean \pm standard deviation The percentages of cells in the $\mathrm{S}$ phase were $24.85 \pm 0.85,31.46 \pm 0.98$ and $42.66 \pm 1.12 \%$ after $24 \mathrm{~h}$ treatment with $0.105,0.21$, and $0.42 \mathrm{mg} / 1$ cinobufacini, respectively. These values were significantly higher than the control group after $24 \mathrm{~h}$ $(19.16 \pm 0.76 \%)$, which suggested that treatment with cinobufacini led to an accumulation of HepG-2 cells in the $\mathrm{S}$ phase in a dose-dependent manner. ${ }^{* *} \mathrm{P}<0.01$ group following $24 \mathrm{~h}$ treatment $(19.16 \pm 0.76 \% ; \mathrm{P}<0.05)$, which suggested that treatment with cinobufacini led to an accumulation of HepG-2 cells in the $\mathrm{S}$ phase and demonstrated dose-dependency (Fig. 3). This result suggested that cinobufacini injection effectively induced cell cycle arrest at the $\mathrm{S}$ phase in the HepG-2 cells.

Cinobufacini injection inhibits the mRNA expression levels of TOPO I and TOPO II in Hep G-2 cells. Following treatment with cinobufacini injection at different concentrations $(0.105$, 0.21 and $0.42 \mathrm{mg} / \mathrm{l}$ ) for $48 \mathrm{~h}$, a dose-dependent decrease in the mRNA expression levels of TOPO I and TOPO II was observed in the HepG-2 cells, as shown in Fig. 4. The ratios of TOPO I/ $\beta$-actin following treatment with 0.105 , 0.21 and $0.42 \mathrm{mg} / 1$ cinobufacini $(0.73 \pm 0.04,0.55 \pm 0.02$ and $0.46 \pm 0.03$, respectively) were significantly lower compared with that observed in the control group $(0.91 \pm 0.04 ; \mathrm{P}<0.05)$, and the ratios of TOPO II $/ \beta$-actin $(0.94 \pm 0.05,0.79 \pm 0.03$ and $0.44 \pm 0.02$, respectively) were significantly lower compared 
A

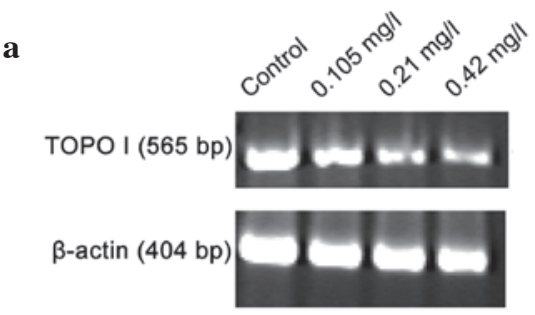

b

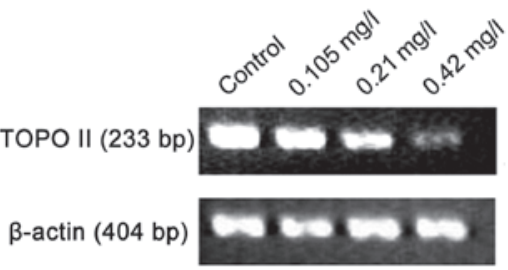

B

a

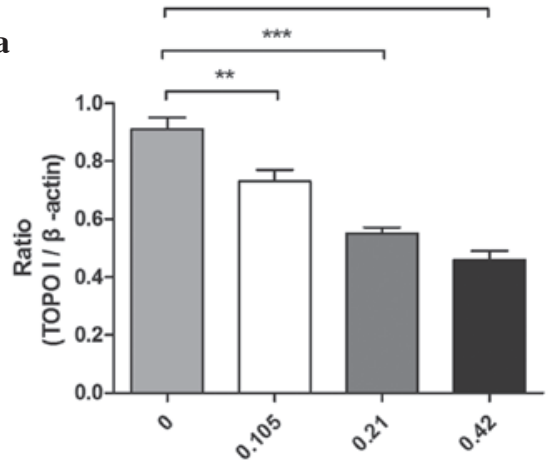

Cinobufacini injection concentration $(\mathrm{mg} / \mathrm{l})$

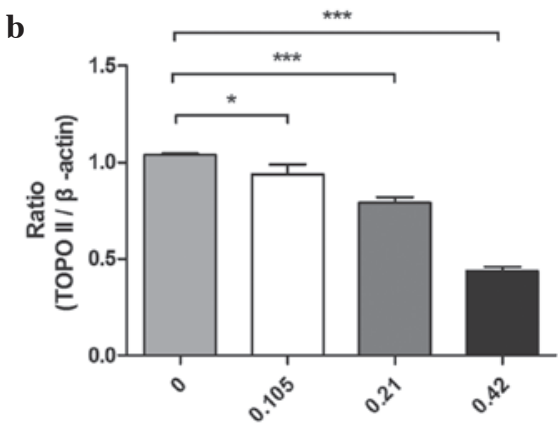

Cinobufacini injection concentration (mg/)

Figure 4. Cinobufacini injection inhibits the mRNA expression levels of TOPO I and TOPO II in HepG-2 cells. The data are expressed as the mean \pm standard deviation. (A) mRNA expression levels of TOPO I and TOPO II following treatment with cinobufacini $(0.105,0.21$ and $0.42 \mathrm{mg} / \mathrm{l})$ for $48 \mathrm{~h}$ in HepG-2 cells. (a) mRNA expression levels of TOPO I and $\beta$-actin, and (b) TOPO II and $\beta$-actin, following treatment with different doses of cinobufacini $(0.105,0.21$ and $0.42 \mathrm{mg} / \mathrm{l})$. (B) Ratios of the mRNA expression levels of TOPO I/ $\beta$-actin and TOPO II $/ \beta$-actin. The ratios of TOPO $\mathrm{I} / \beta$-actin following treatment with $0.105,0.21$ and $0.42 \mathrm{mg} / \mathrm{L}$ cinobufacin $(0.73 \pm 0.04,0.55 \pm 0.02$ and $0.46 \pm 0.03$, respectively) were significantly lower compared with that of the control group $(0.91 \pm 0.04 ; \mathrm{P}<0.05)$ and the ratios of TOPO II $/ \beta$-actin $(0.94 \pm 0.05,0.79 \pm 0.03$ and $0.44 \pm 0.02$, respectively) were significantly lower compared with that of the control group (1.041 \pm 0.06 $\mathrm{P}<0.05$ ), in a dose-dependent manner. (a) Ratios of TOPO I/ $\beta$-actin following treatment with different doses of cinobufacini $(0.105,0.21$ and $0.42 \mathrm{mg} / \mathrm{l})$ for $48 \mathrm{~h}$. (b) ratios of TOPO II/ $\beta$-actin following treatment with different doses of cinobufacini $(0.105,0.21$ and $0.42 \mathrm{mg} / \mathrm{l})$ for $48 \mathrm{~h}$. TOPO, topoisomerase. ${ }^{*} \mathrm{P}<0.05 ;{ }^{* *} \mathrm{P}<0.01 ;{ }^{* * * *} \mathrm{P}<0.005$.

with that observed in the control group $(1.041 \pm 0.06 ; \mathrm{P}<0.05)$. These results demonstrated that cinobufacini injection inhib-
A

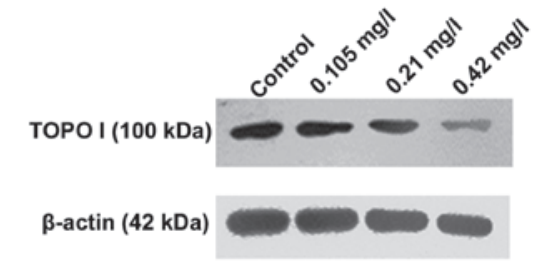

b

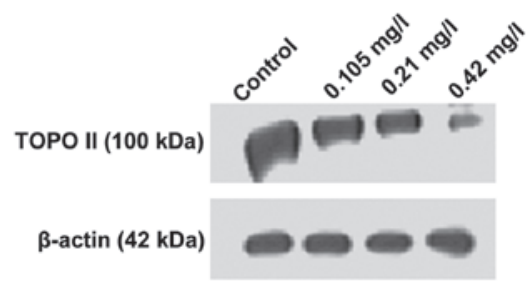

B

a
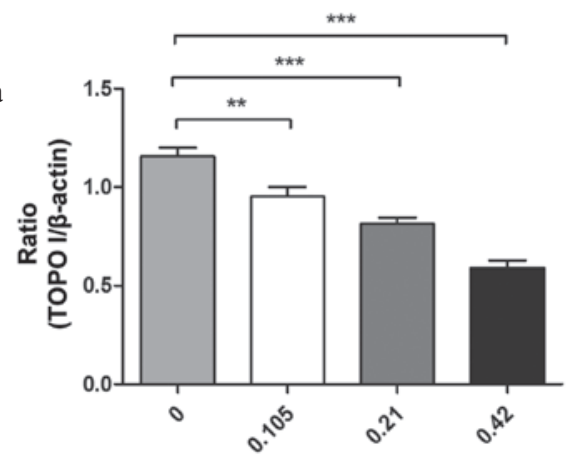

Cinobufacini injection concentration $(\mathrm{mg} / \mathrm{l})$

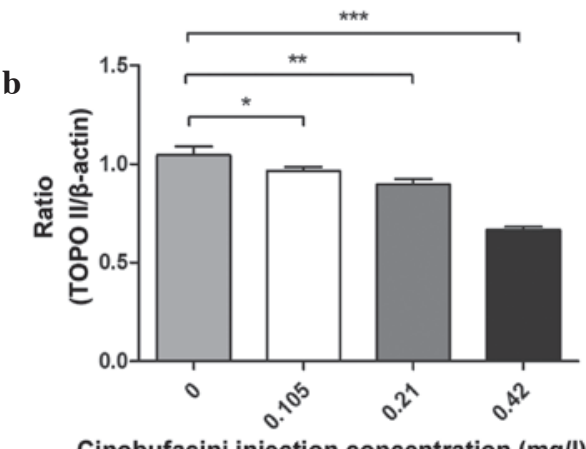

Cinobufacini injection concentration (mg/l)

Figure 5. Cinobufacini injection inhibits the protein expression levels of TOPO I and TOPO II in HepG-2 cells. The data are expressed as the mean \pm standard deviation. (A) Protein expression levels of TOPO I and TOPO II following treatment with cinobufacini $(0.105,0.21$ and $0.42 \mathrm{mg} / \mathrm{l})$ in HepG-2 cells. (a) Protein expression levels of TOPO I and $\beta$-actin, and (b) TOPO II and $\beta$-actin, following treatment with different doses of cinobufacini $(0.105,0.21$ and $0.42 \mathrm{mg} / \mathrm{l})$. (B) Ratios of the protein expression levels of TOPO I/ $\beta$-actin and TOPO II/ $\beta$-actin. Following treatment with cinobufacini $(0.105,0.21$ and $0.42 \mathrm{mg} / \mathrm{l})$. The ratios of TOPO I/ $\beta$-actin following treatment with $0.105,0.21$ and $0.42 \mathrm{mg} / 1$ cinobufacini $(0.954 \pm 0.047,0.816 \pm 0.031$ and $0.592 \pm 0.036$, respectively) were significantly lower compared with that of the control group $(1.157 \pm 0.045 ; \mathrm{P}<0.05)$, and the ratios of TOPO II/ $/$-actin $(0.967 \pm 0.017,0.897 \pm 0.027$ and $0.667 \pm 0.015$, respectively) were significantly lower compared with that of the control group $(1.047 \pm 0.043 ; \mathrm{P}<0.05)$, in a dose-dependent manner. (a) Ratios of TOPO I/ $\beta$-actin following treatment with different doses of cinobufacini $(0.105,0.21$ and $0.42 \mathrm{mg} / \mathrm{l})$, (b) Ratios of TOPO II $/ \beta$-actin following treatment with different doses of cinobufacini $(0.105,0.21$ and $0.42 \mathrm{mg} / \mathrm{l}) .{ }^{*} \mathrm{P}<0.05 ;{ }^{* * *} \mathrm{P}<0.01 ;{ }^{* * *} \mathrm{P}<0.005$. TOPO, topoisomerase.

ited the transcription of TOPO I and TOPO II in the HepG-2 cells, which was observed to occur in a dose-dependent manner. 
Cinobufacini injection inhibits the protein expression levels of TOPO I and TOPO II in HepG-2 cells. Following treatment with cinobufacini injection $(0.105,0.21$ and $0.42 \mathrm{mg} / \mathrm{l})$, the ratios of TOPO I/ $\beta$-actin $(0.954 \pm 0.047,0.816 \pm 0.031$ and $0.592 \pm 0.036$, respectively) were significantly lower compared with that observed in the control group $(1.157 \pm 0.045 ; \mathrm{P}<0.05)$, and the ratios of TOPO II $/ \beta$-actin $(0.967 \pm 0.017,0.897 \pm 0.027$ and $0.667 \pm 0.015$, respectively) were significantly lower compared with that observed in the control group $(1.047 \pm 0.043 ; \mathrm{P}<0.05$; Fig. 5). These results suggested that cinobufacini injection inhibited the protein expression levels of TOPO I and TOPO II in the HepG-2 cells, and that this occurred in a dose-dependent manner.

\section{Discussion}

Clinical trials since the 1970 s have demonstrated that cinobufacini injection exhibits high efficacy against hepatocarcinoma (16) and it has being used in Phase II clinical trials at the MD Anderson Cancer Center (Houstan, USA) (17). Previous clinical studies have indicated that cinobufacini injection exhibits high efficacy against tumor tissues, either alone or in combination with conventional treatment, including chemotherapy and radiotherapy. Additionally, cinobufacini increases physical immunity and improves the quality of life of patients (18). Preliminary studies have demonstrated that cinobufacini injection can induce tumor cell apoptosis, regulate the expression of tumor-associated genes and inhibit tumor angiogenesis and metastasis (19-22). However, to the best of our knowledge, no previous studies have reported the impact of cinobufacini injection on topoisomerases.

Mammalian topoisomerases are enzymes, which are important in regulating the breakage and religation of DNA, providing swivel points for the transcription and replication of DNA, and facilitating the segregation of chromatids prior to mitosis (23). They are classified as TOPO I and TOPO II. TOPO I introduces single strand breaks in the DNA, whereas TOPO II causes transient breaks in pairs of DNA strands (24). Previous studies have demonstrated that the content and activity of topoisomerases in tumor cells is significantly higher than in normal somatic cells. The content of TOPO I is significantly higher in leukemia, colon cancer, cervical cancer and ovarian cancer (25-27), compared with normal cells. TOPO II is highly expressed in laryngeal squamous cell carcinoma, Hodgkin's lymphoma, diffuse large B-cell lymphoma and breast cancer (28). The independent contribution of each enzyme to the regulation of nucleic acid topology configuration is often difficult to assess (29). The fact that topoisomerases are a key requirement in the mammalian cell division cycle makes them important targets for cancer chemotherapy (23). Inhibitors of DNA topoisomerase, including Hydroxycamptotbecine, topotecan, irinotecan, etoposide and teniposide, are widely used as clinical anticancer drugs (30).

In the present study, the effects of cinobufacini injection on the expression of topoisomerases in human hepatocarcinoma HepG-2 cells were investigated. The results indicated that cinobufacini injection significantly inhibited HepG-2 cell proliferation, induced apoptosis and cell cycle arrest at the $\mathrm{S}$ phase and downregulated the mRNA and protein expression levels of TOPO I and TOPO II in a dose-dependent manner. The $\mathrm{S}$ phase is the phase of the cell cycle in which DNA is replicated, occurring between the $G_{1}$ and $G_{2}$ phases. Topoisomerases are significant during the $\mathrm{S}$ phase, and the expression of topoisomerases are key in DNA replication. Therefore, topoisomerases interfere with the replication of DNA in the $\mathrm{S}$ phase and induce cell cycle arrest at this phase, which may lead to apoptosis. As the $\mathrm{S}$ phase is the stage at which DNA replication occurs, and topoisomerase is the key enzyme regulating nucleic acid topology, it is important in DNA replication during the $\mathrm{S}$ phase (31). Decreased expression levels of TOPO I and TOPO II may interfere with DNA synthesis, thereby inducing cell arrest in the $\mathrm{S}$ phase. If the accumulated cells at the $S$ phase fail to pass the S/G2 checkpoint, then the cells may enter the apoptotic program $(32,33)$. Therefore, the results of the present study demonstrated that cinobufacini injection induced HepG-2 arrest at the $\mathrm{S}$ phase and initiated the apoptotic program by interfering with the expression levels of TOPO I and TOPO II. Therefore, cinobufacini offers a promising drug for the treatment of hepatic carcinoma.

\section{Acknowledgements}

This study was supported by funds from the National Natural Science Foundation of China (no. 81173615).

\section{References}

1. Xie RF, Li ZC, Gao B, Shi ZN and Zhou X: Bufothionine, a possible effective component in cinobufocini injection for hepatocellular carcinoma. J Ethnopharmacol 141: 692-700, 2012.

2. Qi F, Li A, Inagaki Y, Kokudo N, Tamura S, Nakata M and Tang W: Antitumor activity of extracts and compounds from the skin of the toad Bufo bufo gargarizans Cantor. Int Immunopharmacol 11: 342-349, 2011.

3. Gong ZP, Chen T: Studies on analgesic mechanism based on opioid receptor for cinobufagin injection. Chin J Exp Tradit Med 16: 120, 2010 (In Chinese).

4. Liu HM, Zheng YL, Liu XL: A Clinical study of efficacy of cinobufagin injection combined with ND formula in medium and advanced esophageal patients. Chin J Exp Tradit Med 17: 235, 2011 (In Chinese).

5. Qi F, Li A, Inagaki Y, Gao J, Li J, Kokudo N, Li XK and Tang W: Chinese herbal medicines as adjuvant treatment during chemoor radio-therapy for cancer. Biosci Trends 4: 297-307, 2010.

6. Su YH, Yin XC, Xie JM, et al: Inhibition effects of three kinds of bufotoxins on human SMMC-7721 and BEL-7402 hepatoma cells lines. Acad J Second Mil Med Univ 24: 393, 2004.

7. Yang LH, Jing XQ, Zhang W: Studies on the chemical constituents from the skin of Bufo bufo gargarizans cantor. J Shenyang Pharm Univ 17: 292-295, 2000.

8. Sun Y, Shi KY: Primary carcinoma of the liver. In: Manual of Medical Oncology (Fifth Edition). Sun Y(ed.) People's medical publishing house, Bei Jing, pp539, 2007.

9. Zhou LX and Guo JM: Research progress in targeted therapy for hepatocellular carcinoma. J Oncol 15: 156, 2009.

10. Cheng AL, Kang YK, Chen Z, et al: Efficacy and safety of sorafenib in patients in the Asia-Pacific region with advanced hepatocellular carcinoma: a phase III randomised, double-blind placebo controlled tril. Lancet Oncol 10: 25-34, 2009.

11. Cui X, et al: New reseach approaches in DNA topoisomerase II targets and antitumor drug. Qingdao Med J 36: 434-437, 2004 (In Chinese).

12. Sun Y, Shan LJ, Liu YJ and Cui XN: The effect of cinobufacini injection on DNA topoisomerase I of human hepatocellular carcinoma HepG-2 cells. Chin J Oncol 19: 410-413, 2010 (In Chinese). 
13. Belluti S, Basile V, Benatti P, Ferrari E, Marverti G and Imbriano C: Concurrent inhibition of enzymatic activity and NF-Y-mediated transcription of Topoisomerase-II $\alpha$ by bis-DemethoxyCurcumin in cancer cells. Cell Death Dis 4: e756, 2013.

14. Bradford, MM: A rapid and sensitive for the quantitation of microgram quantitites of protein utilizing the principle of protein-dye binding. Anal Biochem 72: 248-254. 1976.

15. Stoscheck, CM: Quantitation of protein. Methods Enzymol 182: 50-68, 1990

16. Zhong JS, Chen GP and Guo JW: Clinical observation on HuaChanSu in treating hepatocellular carcinoma after transarterial chemoembolization (TACE). Cancer Prev Treat 29: 67-69, 2002

17. Meng ZQ, Yang PY, Shen YH, et al: Pilot study of huachansu in patients with hepatocellular carcinoma, nonsmall-cell lung cancer, or pancreatic cancer. Cancer 115: 5309-5318, 2009.

18. Qin TJ, Zhao XH, Yun J, Zhang LX, Ruan ZP and Pan BR: Efficacy and safety of gemcitabine-oxaliplatin combined with huachansu in patients with advanced gallbladder carcinoma. World J Gastroenterol 14: 5210-5216, 2008.

19. Yeh JY, Huang WJ, Kan SF anf Wang PS: Effects of bufalin and cinobufagin on the proliferation of androgen dependent and independent prostate cancer cells. Prostate 54: 112-124, 2003.

20. $\mathrm{Yu} \mathrm{CH}, \mathrm{Kan} \mathrm{SF}, \mathrm{Pu} \mathrm{HF}$, Jea Chien E and Wang PS Apoptotic signaling in bufalin- and cinobufagin-treated androgen-dependent and -independent human prostate cancer cells. Cancer Sci 99: 2467-2476, 2008

21. Qi F, Inagaki Y, Gao B, et al: Bufalin and cinobufagin induce apoptosis of human hepatocellular carcinoma cells via Fas- and mitochondria-mediated pathways. Cancer Sci 102: 951-958, 2011.

22. Qi F, Li A, Inagaki Y, et al: Antitumor activity of extracts and compounds from the skin of the toad Bufo bufo gargarizans Cantor. Int Immunopharmacol 11: 342-349, 2011.

23. Denny WA and Baguley BC: Dual topoisomerase I/II inhibitors in cancer therapy. Curr Top Med Chem 3: 339-353, 2003.
24. Fayad W, Fryknäs M, Brnjic S, Olofsson MH, Larsson R and Linder S: Identification of a novel topoisomerase inhibitor effective in cells overexpressing drug efflux transporters. PLoS One 4: e7238, 2009

25. Giovanella BC, Stehlin JS, Wall ME, et al: DNA topoisomerase I-targeted chemotherapy of human colon cancer inxenografts. Science 246: 1046-1048, 1989.

26. Potmesil M, Hsiang YH, Liu LF, et al: Resistance of humanleukemic and normal lymphocytes to drug-induced DNAcleavage and low levels of DNA topoisomerase II. Cancer Res 48: 3537-3543, 1988

27. Rho YH, Lee BW, Park KH, et al: Cudraflavanone A purified from Cudrania tricuspidata induces apoptotic cell death of human leukemia U937 cells, at least in part, through the inhibition of DNA topoisomerase I and protein kinase $\mathrm{C}$ activity. Anti-cancer Drugs 18, 1023-1028, 2007.

28. Pan YQ, Yuan G, Yang YW: DNA topoisomerase II $\alpha$ and tumor. Med Imformation 2: 415, 2011.

29. Squires S, Ryan AJ, Strutt HL, Smith PJ and Johnson RT: Deoxyguanosine enhances the cytotoxicity of the topoisomerase I inhibitor camptothecin by reducing the repair of double-strand breaks induced in replicating DNA. J Cell Sci 100: 883-893, 1991

30. Huang X, Halicka HD, Traganos F, et al: Cytometric assessment of DNA damage in relation to cell cycle phase and apoptosis. Cell Prolif 38: 223-243, 2005.

31. Liu YP, Chen HL, Tzeng CC, et al: TCH-1030 targeting on topoisomerase I induces S-phase arrest, DNA fragmentation, and cell death of breast cancer cells. Breast Cancer Res Treat 138: 383-393, 2013.

32. Hofland K, Petersen BO, Falck J, Helin K, Jensen PB and Sehested M: Differential cytotoxic pathways of topoisomerase I and II anticancer agents after overexpression of the E2F-1/DP-1 transcription factor complex. Clin Cancer Res 6: 1488-1497, 2000.

33. John L. Nitiss and James C. Wang: Mechanisms of cell killing by drugs that trap covalent complexes between DNA topoisomerases and DNA. Mol Harmacology 50: 1095-1102, 1996. 